\title{
A DIRECTIVE SPEECH ACT OF HATE SPEECH ON INDONESIAN SOCIAL MEDIA
}

\author{
Ubaidillah[1], I Dewa Putu Wijana[2]
}

\author{
[1]23ubaid@gmail.com \\ [1]Pusat Penelitian Masyarakat dan Budaya, LIPI. [2]Fakultas Ilmu Budaya, UGM \\ [1]Jakarta Selatan, DKI Jakarta, Indonesia. [2]Sleman, DIY Yogyakarta, Indonesia
}

\begin{abstract}
Hate speech is not only about shared knowledge but also desires and hatred. The purpose of hate speeches is to give the addressee the knowledge unknown before and make them want something never thought of and feel something. This paper describes the type of illocutionary force of hate speech on social media in Indonesia. The utterances used as data have been stipulated by the Indonesian court violating Article 28 and 45a Information and Electronic Transactions Law or article 156a Criminal Code. This article found that the illocutionary forces of hate speeches on Indonesian social media are to express incitement, invitation, order, prohibition, criticism, and warning. The illocutionary functions of these acts are at (1) addressee's compliance upon the will of the speaker; (2) dismantlement of the identity that is the source of the speaker's hatred; or (3) elimination of hatred targets.
\end{abstract}

Keywords: hate speech, directive speech act, pragmatics, information, electronic transactions law

\section{INTRODUCTION}

Hate speech is a global and particular phenomenon. This phenomenon is global because it occurs in many countries with diverse social patterns, while it is said to be particular because the phenomenon in each country has a different thematic style of hate speech. More than half of the hate crimes that occur in the UK are directed against Muslims with thematic topics around Muslim links to terrorism crimes (BBC, 2018) or in general, in the European Union according to Moon (2018, p. 8), hate speech occurs because of European concerns about migration flows. Muslims turn Europe into a Eurobia either through demanding the implementation of sharia law or through violence. This intertwined migration flow, terrorism, and fear of occupation form the thematic features of hate speech in Europe. In African countries, such as Kenya, according to research by Kimotho and Nyaga (2016), hate speech occurs more due to ethnic rivalry among community members. For the Indonesian context, it can be concluded that hate speech occurs in the spirit of religious sentiments, which are sometimes intertwined with ethnicity in the struggle for cultural dominance and formal power.

Hate speech is not just an emotional expression against a particular individual conveyed through interpersonal channels but expressed hatred is based on fundamental human characteristics, such as race, ethnicity, religion, or national origin, and is conveyed through public channels. This public channel factor and fundamental communal character make hate speech can cause mass damage.

Hate speech conveyed through public means has a double direction, aiming to warn the hated party and provoke people to hate. Wardorn (2012, pp. 2-3) gives an example of the phrases 'Muslims and 9/11, Don't serve them, don't speak them, and don't let them in' written on the wall in New Jersey, United States. The public means of utterance makes the illocutionary direction of the action double, namely warning Muslims that they are not accepted as part of the New Jersey City community or if viewed in a propositional utterance that uses them to refer to Muslims 
and the imperative word 'don't' shows that the illocutionary power of speech This is to prohibit the interlocutor from being accepting of Muslims. The speech on the New Jersey City wall is seen from the direction of Muslims as speech partners and people who are prohibited from accepting Muslims; the speaker has taken particular actions in his speech. In the terms introduced by Austin (1968), the above utterance is a performative utterance in which the speaker performs an action in using language and is not producing specific meanings that can be evaluated as true or false.

Therefore, according to Langton (2012, p. 80), speech act analysis can be an alternative way of researching hate speech. This article focuses on directive speech acts of hate speech on social media in Indonesia because directive actions make people attacked by their essential human character and incited by hatred.

\section{Previous Studies}

The results of the questionnaire conducted by Kimotho and Nyaga (2016) also explained that $90.7 \%$ of students believed that hate speech on social media influenced their assessment of the ethnic picture targeted by ethnic hate speech in Kenya. As many as $50.2 \%$ of student respondents also said that reading hate speech directed at their ethnicity made them feel bad or inferior. Thus, apart from being intended to incite the hatred of others, hate speech leads the targeted party to take specific actions based on the proposition of the speech, for example, acts of feeling inferior as in Kimotho and Nyaga's (ibid.) research. This action can be the speaker's intention in producing his utterance, or in other words, the speaker performs the act of ordering with his utterance.

The use of this illocutionary speech act theory is at least helpful to reveal the phenomenon of hate speech from the speaker's perspective. The initial condition that should be sociological in seeing the success of an utterance being an illocutionary act and producing a perlocutionary effect, in this article is seen as a psychological aspect; aspects that describe the world in the perspective of hate speech speakers. This perspective is the same as the research on the illocutionary utterances of Islamophobia in electronic newspapers in the United Kingdom conducted by Lestari (2016). Meanwhile, Ubaidillah (2019a) uses the victim's perspective in researching the discourse behind Papuans responding to racial hate speech against them. Papuans perform a 'resignification' of the word 'monkey' directed to them to fight against the racist perpetrators. Aspects of conventionality in illocutionary acts provide room for deliberation for Papuans to avoid the speaker's intention of wanting them to feel inferior.

\section{METHOD}

This paper uses a pragmatic approach to investigate hate speech on social media in Indonesia. This paper will describe hate speech on social media based on the type of directive illocutionary based on its function and the factors that influence the type of directive speech act of hate speech on social media in Indonesia based on a pragmatic approach. The utterances that become the data in this article have the following criteria.

- Spoken and written utterances are in Indonesian because, as the national and official language, it is mastered both passively and actively by all Indonesians, thus enabling interpreting speech by the speech partners.

- Speeches are spoken on social media (Facebook, Twitter, Instagram, Path, WhatsApp, BBM, Line, Youtube, and others).

- The Indonesian court has stipulated the statement as violating articles 28 and 45a of Law no. 19 of 2016 concerning Information and Electronic Transactions (UU ITE) or article 156a of the Criminal Code. Both of these criminal rules regulate criminal acts based on public statements. The second thing is that the limits on statements of hostility, hatred, and insults in Article 28 45a of the ITE Law include individuals or groups based on ethnicity, religion, race, and intergroup (SARA). At the same time, Article 156a of the Criminal Code is specific to certain religious entities. Although there are differences in legal subjects between the two articles: the ITE Law presupposes that the legal subject is individual or group human beings, while 
the Criminal Code article regulates criminal acts against religious entities, in the context of hate speech, poor representation of religion is prone to the misrepresentation of the religious community as a whole (Ubaidillah, 2019b). Aggression against religion has an impact on the people of that religion.

Concerning the criteria for the data, the data source is a copy of the court's decision. The data source was chosen considering that the copy of the court's decision contained utterances and contextual evidence regarding the speaker and speech partner, such as the chronology of utterance and its interpretation. This article analyzes four court decisions involving the defendants Feriyanto, Leogok Rezeky Gultom, and Faizal Muhammad Tonong, who were found guilty of violating Articles 28 and 45a of the ITE Law Rozaq Ismail Sudarmadji, who was found guilty of violating Article 156a of the Criminal Code. Other things that are not directly related to the utterances and contextual evidence contained in copies of court decisions, such as statements of expert witnesses and others, do not serve as primary data for this paper because these statements are other interpretations of parties who are not involved in the roles of speakers and speech partners.

The data that has been collected is then analyzed based on the type of directive illocutionary speech act and the factors that influence the type of directive speech act. The analysis was carried out using a pragmatic approach, namely studying language use in specific contexts. Thus, data analysis does not only involve linguistic contexts but is broader than that such as social, political, cultural, and historical contexts because, in pragmatics, speech or utterances are concrete entities that are clearly defined by the speaker, speech partner, time, and place of speech (see Wijana \& Rohmadi, 2011, p. 17).

\section{RESEARCH RESULT}

\section{Types of Directive Speech Acts of Hate Speech on Indonesian Social Media}

This directive speech act analysis is an analysis of the actions taken by the speaker from the speaker's perspective. Therefore, the analysis of this section does not intend to reconstruct the judges' considerations so that they find the speaker of this speech guilty of being the perpetrator of hate speech. However, there may be types of directive acts described here that are taken into consideration by the panel considering the potential for violence or damage caused by the utterances. The data for this research.

\section{Speech Act of Incitement}

Speech (1) is an act of incitement carried out by Feriyanto. This type of directive speech act is known based on contextual and contextual factors. The utterance (1) itself was said after Feriyanto said status "Saya mengajak rekan-rekan dari pool ME, pool MT, pool MJ, pool JE, pool JU, pool BDE, pool LL, pool LR, pool YD, pool OE, pool TJ, pool TT, pool GDD, pool MWK, dan semua supir taksi seJabodetabek untuk menghadiri demo besarbesaran pada hari Selasa 22 Maret 2016 di depan Istana Merdeka. Jangan lupa bawa benda tumpul dan tajam, kalau perlu bom molotop, antisipasi jikalau Uber sama Grab lewat, langsung bantai." The utterance becomes a contextual factor that explains the reference to the phrase "alat perang" below.

(1) alat perang untuk tanggal 22 Maret 2016

(tools of war for March 22, 2016)

Context: utterance (1) is a photo caption with a picture of a sword and sickle uploaded by Feriyanto on his Facebook account.

Contextually the utterance explains that the sword and sickle contained in the photo and is called a tool of war in utterance (1) will be used to slaughter Uber and Grab. The word war entails that the events of March 22, 2016, have two hostile participants fighting each other, so that utterance (1) has two potential participants that Feriyanto addresses based on his proposition. The statement (1) if addressed to Uber and Grab drivers who became enemies in the war on March 22, 2016, statement (1) becomes a threatening act by Feriyanto to the driver because swords and sickles, which are called tools of war, will be used to slaughter them. However, if interpreted by the participants of the massive demonstration on March 22, 2016, the statement (1) is an act of inviting the action 
participants to bring weapons of war also because of the relationship between speech (1) and the speech Jangan lupa bawa benda tumpul dan tajam, kalau perlu bom molotop, antisipasi jikalau Uber sama Grab lewat, langsung bantai. These two types of potential speech partners are a consequence of Facebook's public facility to be interpreted by many people. However, the intended speech partner of utterance (1) is another Blue Bird taxi driver, so that utterance (1) is a directive speech act with an instigating function performed by Feriyanto.

The illocutionary utterance (1) direction is still related to the utterance (2), which becomes its context. The contextual utterance is addressed to Blue Bird taxi drivers or prospective participants of the March 22, 2016 demonstration and contains the proposition 'Jangan lupa bawa benda tumpul dan tajam antisipasi jikalau Uber sama Grab lewat, langsung bantai.' The sword and sickle in the picture are classified as a sharp weapon mentioned in the speech to slaughter Grab and Uber drivers. Speech (2) shows other Blue Bird taxi drivers that Feriyanto did what the contextual utterance suggested, namely carrying sharp weapons to kill Grab and Uber drivers. The contextual utterances that were said earlier have become the contextual knowledge of the Blue Bird taxi driver so that this knowledge forms the reasoning of the speech partners that Feriyanto has prepared what he invited and wants other Blue Bird taxi drivers to do the same. In addition, the contextual factor of Feriyanto's Facebook account, which contains more friendships with other Blue Bird drivers, makes the statement (2) aimed at other Blue Bird drivers. Therefore, utterance (1) is a directive speech act that inciting the speech partners of other Blue Bird taxi drivers to carry weapons to kill Grab and Uber drivers on March 22, 2016.

\section{Speech Act of Invitation}

Feriyanto said speech (2) on his Facebook account. This utterance (2) uses performative verbs to indicate the utterance's illocutionary force, namely the verb to invite. However, utterance (2) is also composed of two sentence constituents which indicate two types of directive speech acts, namely inviting and reminding. If the speech act of inviting is marked by the verb inviting, the speech act of reminding is indicated by using the word negation, not for actions that the speaker does not want, namely forgetting. The act of reminding does not entirely correspond to the locution, but the speaker wants an action that negates forgetting through an implicature process. However, the contextual relation between the first and second sentences cannot make them analyzed separately. The second sentence is also proportionally tied to the second sentence. This attachment can be demonstrated by the question 'when will the weapons to kill Grab and Uber be brought?'. The answer to this question is contained in the first sentence, namely at the State Palace demonstration on March 22, 2016.

(2) Saya mengajak rekan-rekan dari pool $M E$, pool MT, pool MJ, pool JE, pool JU, pool $B D E$, pool $B D U$, pool $L L$, pool $L R$, pool LR, pool YD, pool OE, pool TJ, pool $T T$, pool GDD, pool MWK, dan semua sopir taksi sejabodetabek untuk menghadiri demo besar-besaran pada hari Selasa tanggal 22 Maret 2016 di depan Istana Negara. Jangan lupa bawa benda tumpul dan tajam, kalau perlu bom molotop, antisipasi jikalau Uber dan Grab lewat, langsung bantai.

(I invite colleagues from pool ME, pool MT, pool MJ, pool JE, pool JU, pool BDE, pool BDU, pool LL, pool LR, pool LR, pool YD, pool OE, pool TJ, pool TT, pool GDD, MWK pool, and all taxi drivers from all over Jabodetabek to attend a massive demonstration on Tuesday, March 22, 2016, in front of the State Palace. Do not forget to bring a blunt and sharp object or a Molotov cocktail; anticipate if Uber and Grab [drivers] pass by, kill them immediately.)

Context: utterance (2) was said by Feriyanto on his Facebook account.

In addition to the propositional linkage, the second sentence cannot be said to be an act of reminding performed by Feriyanto because this action requires an initial condition or the interlocutor has been informed before Feriyanto utters the utterance (2). All of Feriyanto's Facebook account uploads that were traced did not contain any posts related to the notification to 
carry weapons at the demonstration on March 22, 2016.

There are two future actions that Feriyanto wants the interlocutor to take, namely conducting or participating in a demonstration on March 22, 2016, and carrying weapons during the demonstration. However, the two activities are not mutually exclusive but are subordinated to each other. The act of carrying weapons is included in the act of attending or participating in demonstrations. Therefore, the second sentence of speech constituent (2) is also a speech act of inviting and the first sentence. Speech (2) is the act of inviting the interlocutor to demonstrate on March 22, 2016, and carrying weapons at the demonstration. The speech partners in the speech event (2) are Blue Bird taxi drivers and other taxi drivers from Jabodetabek, as mentioned in the speech.

\section{Speech Act of Prohibition}

Utterance (3) 'mengenal Islam dari sejarah nabinya, pemimpin perang, membunuh banyak orang, memperkosa banyak korban perang, mengawini banyak perempuan, mati diracuni oleh istrinya. Jangan terlalu percaya dengan buku alkorannya (Al-Qur'an), karena buku alkoran itu karangan sastra, bukan tulisan Muhammad karena Muhammad tidak pandai baca dan menulis' is a photo caption that depicts a man holding a sword and contains the words 'Wajah Muhammad direkonstruksi berdasarkan ayat Al-qur'an: pembunuh (33:26), hidup dari rampasan (8:21) dan main perempuan (2.223 \& 33:37)' which was made by Leogok Rezeky Gultom's Facebook profile photo. Thus the two have a contextual connection. Therefore, these two utterances will be analyzed by considering them as a unit as speech (3). The part of the first sentence of the statement in bold still has a propositional connection with the elements, such as pembunuh, hidup dari rampasan perang, dan main perempuan contained in the photo.

(3) Wajah Muhammad direkonstruksi berdasarkan ayat Al-qur'an: pembunuh (33:26), hidup dari rampasan (8:21) dan main perempuan (2.223 \& 33:37). Mengenal Islam dari sejarah nabinya, pemimpin perang, membunuh banyak orang, memperkosa banyak korban

\begin{abstract}
perang, mengawini banyak perempuan, mati diracuni oleh istrinya. Jangan terlalu percaya dengan buku alkorannya (Al-Qur'an), karena buku alkoran itu karangan sastra, bukan tulisan Muhammad karena Muhammad tidak pandai baca dan menulis.

(Muhammad's face is reconstructed based on the verses of the Qur'an: murderer (33:26), living off the spoils of war (8:21), and playing with women ( 2223 \& 33:37). Knowing Islam from the history of its Prophet, led war, killed many people, raped many war victims, married many women, died poisoned by his wife. Do not trust the Qur'an too much because it is a literary work, not Muhammad's writing because he was illiterate.)

Context: utterance (3) is a photo caption and utterance contained in a picture of a man holding a sword uploaded and became the profile photo of Leogok Rezeky Gultom's Facebook account.
\end{abstract}

The utterances in the photo and the first sentence of utterance (3) are the reasons for Leogok's prohibition in utterance (3). The speech act of prohibiting itself is marked by the use of the imperative word do not. Judging from the use of the phrase overconfidence as an act prohibited by Leogok, it implies that the speech partner who is the target of the action is a person who already has faith in the Qur'an because what Leogok prohibits is the level of trust in the Qur'an which is too inappropriate forbids Muslims not to believe. However, the word can also be used ironically. The illocutionary act (3) is that Muslims are prohibited from believing in the Qur'an. This ironic meaning is formed due to the relationship between Muhammad and the Qur'an, which is described that the Qur'an is only made for Muhammad's sake so that he can kill, play with women, and get the spoils of war. Such representation of Muhammad delegitimizes the validity of the Qur'an so that it does not deserve to be believed.

The first and second sentences function to legitimize the actions of prohibiting the speaker. The function depends on the 
conditions for the prohibiting speech act, which the addressee may follow if the action is carried out by a speaker having a higher position than the interlocutor. The speaker views the propositions of the first and second sentences as the factual truth of the Prophet Muhammad. In other words, the source of the speaker's authority to do the prohibiting action is knowledge of the truth, and he feels that people who do not share the knowledge or even believe the contrary are the people who should obey the prohibition. The truth of the Qur'an, Muhammad, and Islam that is not known to Muslims according to the speaker gives him the authority to prohibit and make the interlocutor realize that the speech partner knows the reason why he must obey the speaker's diabolical plan.

\section{Speech Act of Command}

Speech (4) is a directive illocutionary speech act with a commanding function performed by Leogok to the commentator of the profile photo with a picture of a man holding a sword and containing speech (3). Speech (4) still has a relationship with the propositions of the previous utterances. The phrases of the Prophet who are farts and killers refer to the Prophet Muhammad, and these phrases are a derivative form of the attribution of the Prophet Muhammad as a murderer and (like) playing with women contained in utterance (3). Leogok believes these attributions of the Prophet Muhammad were proper and adequate to make people who believe in the Prophet feel ashamed.

(4) Gk mlu kw pny nabi tukang kentot dan tukang bunuh

(Aren't you ashamed to have a prophet who loves sex and a murderer?)

Context: remarks (4) are said in the comments column in response to comments on status uploads on Leogok Rezeky Gultom's Facebook account

The form of speech sentence (4) is an interrogative sentence. In Indonesian, especially in spoken conversation, interrogative sentences can begin with a negation word such as the word no to ask for specific actions that can or should be done by the interlocutor, for example, tidak tidur?, tidak mandi?, atau tidak jadi pergi?. According to Leech (1993: 59), speech acts that are conveyed in the form of other actions, such as the act of ordering in the form of asking, are utterances that contain implicatures, and in the case of speech (4), the implicature is that the speaker wants the speech partner to feel ashamed of having a prophet who is a tukang kentot (adulterer) and tukang bunuh (murderer). Therefore, the illocutionary act (4) is a command.

Speech (4) comes up from an evaluation process of two things, namely the evaluation of the qualifications of Muhammad (PBUH), whom he believed to be a murderer and liked to play with women, which was measured by the ethical standards he believed in so that he produced the qualifications of the Prophet Muhammad SAW that was enough to make people believe in him as a prophet feel ashamed. The word no that begins the question mentioned above can be used to ask an action taken by the speech partner. Therefore, from the form of the interrogative sentence (4), which begins with the word negation gk (no), it can be assumed that the speech partner does not show shame for his belief in the Prophet Muhammad as should be according to Leogok's belief so that Leogok uses the form of negation in his speech. The illocutionary speech act of telling the utterance (4) can be changed into direct form such as 'Kau harus malu punya nabi tukang kentot dan tukang bunuh!'.

\section{Speech Act of Criticizing}

Speech (5) is an utterance belonging to Rozaq Ismail Sudarmadji on his Facebook account. Rozaq Ismail Sudarmadji's words are still related and are in the socio-political context of the DKI Jakarta Regional Head Election. Although administratively, Rozaq is a resident of Wonosobo, he does not have political rights in the Gubernatorial election in Jakarta. However, Jakarta's election cannot be viewed solely from an administrative perspective because the politics of religious identity color this political contestation. Religious identity politics makes a religion universal and transcends administrative boundaries, involving people outside DKI Jakarta who practice the same religion. One of the reasons for strengthening religious identity politics in the election is that Basuki 
Tjahja Purnama or Ahok, one of the candidates, was involved in a blasphemy case, leading to a series of protests by groups behalf of Indonesian Muslims. Ahok's religion, which is Catholic Christianity, is also an essential part of making religious identity politics more salient and significant because the doctrine that it is forbidden to choose infidel leaders in terms of adherents of religions other than Islam has colored the struggle for political power in DKI Jakarta. Rozaq Ismail Sudarmadji is in such a social context, and his utterance can only be reviewed based on that same context.

Rozaq Ismail Sudarmadji is a Muslim, and he knows that Islam is not divided by region, let alone an administrative region like Indonesian Islam. However, he violates the maxim of quality-saying something he knows is wrong to achieve a particular purpose. The phrase Indonesian Islam implies that Rozaq Ismail Sudarmadji divides and differentiates Islam; he simply fragments the universal religion of Islam, does not teach insults to other religions and Islam in Indonesia that criticizes other religions. The phrase Indonesian Islam which criticizes other religions, even if it is viewed in the sociopolitical context of Jakarta's election, is also specific; namely, it leads to the political representation of religious identity in the arena of the struggle for political power. Therefore, if Indonesian Islam is understood literally without linking its socio-political context and Rozaq Ismail Sudarmadji's individual, it will make the phrase false in objective truth. However, suppose we link the two contexts. In that case, it can be understood that the reference to Islam in Indonesia, which is the only religion that likes to criticize other religions, is Islam which appears in the identity politics of the 2017's DKI Jakarta election, and not Islam universally. Therefore, this utterance can have a sarcastic meaning that does not have a literal meaning.

The function of criticizing conveyed by utterance (5) is not in line with the meaning of the words that compose the utterance is determined based on the socio-political context of the existence of the utterance and individual factors of Rozaq Ismail Sudarmadji. The socio-political factor of the DKI Jakarta gubernatorial election, which is full of religious identity politics, is one of the critical contexts to explain the utterance (5) because Islamic religious identity politics is the reference of the phrase agama Islamnya Indonesia. The phrase agama Islamnya Indonesia represents that Islam is fragmented based on administrative boundaries, even though one of the characteristics of a religion is that it is universal across administrative and even cultural boundaries. It can be said that the elements of geographical area and religion cannot be combined. Rozaq Ismail Sudarmadji, as a Muslim, also knows the truth that Islam is universal and not fragmented by region. However, he still uses the phrase for a specific function, namely criticizing - changing reality to serve what he wants, namely speech partners - adherents of Islam - Stop using religion to be part of the way to win political contestations that make Islam look like a religion that likes to criticize other religions. The act of criticizing that is conveyed sarcastically by generalizing Islam is to increase the power of pointing out errors or inaccuracies made by the speech partner so that the speech partner takes the desired action by the speaker.

(5) Satu satunya agama yang suka mencaci agama lain adalah agama Islamnya Indonesia.

(The only religion that likes to criticize other religions is Indonesian Islam.)

Context: utterance (5) spoken through the Facebook account status of Rozaq Ismail Sudarmadji

The criticism was aimed to criticize the use of Islam in regional head elections because the Islam that appeared in the event was not following Islamic teachings believed by Rozaq Ismail Sudarmadji. Rozaq compares and evaluates the religion of Islam that appears in the political arena based on the universal teachings of Islam that he believes in. The results of these comparisons and evaluations made Rozaq feel that Islam appearing in the political arena was not following Islamic teachings, so it had to be stopped. Therefore, the speech partners (5) are Muslims because only Muslims can stop the use of Islam in identity politics. Muslims can stop because they carry out identity politics, either because of mobilization or volunteerism. The function of criticizing the directive speech act (5) seeks 
to make the speech partner stop and change.

\section{Speech Act of Warning}

Speech (6) which is Faizal Muhammad Tonong's utterance on Facebook social media, contains future events that speakers believe have a detrimental impact on the speech partner. This condition is the same as stated by Searle (1969: 67) that the condition of preparing an act of warning because future events intended by the speaker in his speech have a detrimental effect on the hearer. The detrimental impact is contained implicitly in the phrase for the sake of posterity. The word for can be paraphrased more explicitly, indicating that the future action intended by the speaker must be realized by the speech partner for the benefit of children and grandchildren or future generations. The future action is to avoid or counteract efforts to make future generations embrace PKI's (Indonesian Communist Party) ideology and become the slaves of the People's Republic of China (PRC).

(6) Demi anak cucu, jangan sampai dijadikan anak2 pki dan budak2 antek $R R C$

(For the sake of [our] posterity, never let them be PKI [communist] and the PRC's allies!)

Context: utterance (6) submitted through the Facebook account of Faizal Muhammad Tonong belonging to Muhammad Faizal Tanong.

During Joko Widodo's administration, the socio-political context is hugely stigmatized as the Communist ally (the Indonesian Communist Party and the ruling Communist Party in China) by some people because his economic policies tend to cooperate with the People's Republic of China. So that implicitly the parties What has made future generations the children of the PKI and slaves of the PRC is the government of President Joko Widodo. Faizal Muhammad Tonong's Facebook account, earlier on May 18, 2016, wrote '27 FACTS JOKOWI IS A PKI cadre \& DESCRIPTION', which included a page address detailing the 27 facts mentioned that Faizal Muhammad Tonong had provided background knowledge to the interlocutor who was connected through the media. Facebook social media regarding the reference from those who will make the cadre of the PKI and slaves of PRC is the government of President Joko Widodo.

The speech partner (6) implies from the explanation about the Communist minions above, especially from the administrative relations of President Joko Widodo. The presidential administrative relationship presupposes that President Joko Widodo's authority is limited to a particular administrative area, namely Indonesia's territory. Therefore, the effort to make the children of the PKI and the slaves of PRC henchmen was limited to the administrative area of Indonesia, so that the speech partners (6) were Indonesian people. The phrase for the sake of posterity in the utterance (6) specifies the classification of the Indonesian people who are the speech partners, namely the Indonesian adults who have descendants, either children or grandchildren. Today's Indonesian people refer to those who already have the right to vote in the Indonesian presidential election because the avoidance of becoming the children of the PKI and the slaves of the PRC's stooges can only be realized by not re-electing Joko Widodo in the 2019's Presidential election.

Speakers in addition to saying utterances that have negative sentiments against the PKI, PRC (Tiongkok), China, and President Joko Widodo, also upload utterances that attract sympathy, solidarity, or empathy for Muslims, such as 'MESKI AL-QUR'AN DIBAKAR CHINA KAFIR UMAT ISLAM MAMPU MENAHAN DIRI', dan 'SAYA YAKIN \& PERCAYA.. sehebat hebat apapun rencana dan strategi mereka berkonpirasi hancurkan islam demi tujuan kristenisasi berkolaborasi dengan mimpi NEO.KOMUNIS..2019...'. In short, speakers upload utterances with nationalist and religious sentiments alternately and at the same time to make people reading their posts not choose Joko Widodo as president. The intertextuality of these utterances can describe the speech partners (6), the Indonesian people who have the right to vote, and the Muslims in Indonesia. These utterances can be said to be part of the utterances of political contestation carried out by the public to win one of the candidates who are supported or not supported. The ultimate 
perlocutionary effect of the utterance leads to the voice booth. Therefore, even though this utterance is done individually, it is a practical political utterance.

\section{DISCUSSION}

\section{Hatred in the Speaker's Perspective}

Understanding hate speech on social media in Indonesia. Therefore, the aspects that surround the speaker will be discussed in more depth and detail in this section. However, the analysis still requires an explanation of the components of speech events, such as the verbal product, time, and place of speech mentioned by Leech (1993, pp. 19-22) or the form and content of the message, typical environmental devices such as time and place, involving language use, the purpose and impact of communication, keys or instructions, intermediaries, genres, and communication norms (Halliday, 1994, pp. 1112) All the factors mentioned above can be grouped into two types of factors, namely lingual factors, and extra lingual factors. This section will describe the factors that influence the types of directive speech acts of hate speech on social media in Indonesia.

Table 1 shows a summary of the speech participants, the content of the message, the hated party in the utterance, and the illocutionary function of the utterance. The speaker's identity listed in the table is only the identity of the antagonist in the content of the message. This identity conflict is the key to explaining the world, as seen by the speaker. As Sternberg and Sternberg (2008, pp. 174176) emphasized, the speaker's identity can explain passion as a component of hatred and negation intimacy and commitment. The element of passion contains an understanding of the focus of attention of someone who is harmed or not ideally desired to raise anger about the situation.

All of the speakers discussed show one focus of attention in their lives which causes them to experience anger and hatred towards the other party. Speakers (1) and (2) feel that the presence of Uber and Grab drivers make their incomes decrease because they cannot compete with them. His identity as a taxi driver makes him hate Uber and Grab drivers. Before uploading remarks (3) and (4), the speakers were involved in a heated debate about Christianity and Islam on the Facebook group. Speakers (3) and (4) feel annoyed and angry that adherents of other religions are despising their identity as Christians. Then, he uploaded remarks (3) and (4) on his Facebook account showing the inferiority of the religion held by people who insulted and in itself showed the superiority of the religion he professed. The meaning of the phrase "Indonesian Islam" spoken by the speaker (5) is Indonesian people who are Muslim, more specifically Muslims in Indonesia who use Islamic religious sentiments in the DKI Jakarta Pilkada. Speech speaker (5) also uploaded 'ternyata riziq shihab tukang ngelonthe $H R$. BUKHARI MUSLIM' on his Facebook account. The contextual linking of the two speaker's utterances (5) shows more precisely the meaning of agama Islamnya Indonesia because Muhammad Rizieq Shihab, the Jakarta-based Islamic Defenders Front leader, is actively campaigning to elect a governor of the same religion. Although it is only said to be of the same religion, when viewed from the election contestants, which are only filled by two pairs of candidates for governor-deputy governor, one of which is a Catholic, namely Basoeki Tjahja Purnama, by itself the campaign is intended to direct people to vote for Anies Baswedan who is Muslim. The speaker (5) considers the political contestation that uses such religious sentiments to be incorrect; his identity as a Muslim feels that his religion is being abused, making him angry. Meanwhile, the speaker (6) considers that if Joko Widodo wins the presidential election, it will be a threat to the existence of Muslims.

Tabel 1. Komponen Peristiwa Ujaran Kebencian di Media Sosial di Indonesia

\begin{tabular}{cccccc}
\hline Utterance & Speaker & $\begin{array}{c}\text { Speaker's } \\
\text { Identity }\end{array}$ & Interlocutor & \multicolumn{1}{c}{ Message } & The Hated Parties \\
\hline 1 & Feriyanto & Taxi Driver & Taxi & $\begin{array}{l}\text { Instigating speech } \\
\text { partners to commit } \\
\text { violence against Uber } \\
\text { and Grab drivers } \\
\text { during the }\end{array}$ & $\begin{array}{l}\text { Uber and Grab } \\
\text { Driver }\end{array}$ \\
& & & & &
\end{tabular}




\begin{tabular}{|c|c|c|c|c|c|}
\hline & & & & demonstration & \\
\hline 2 & Feriyanto & & & $\begin{array}{l}\text { Inviting speech } \\
\text { partners to murder } \\
\text { Uber and Grab drivers } \\
\text { during the } \\
\text { demonstration }\end{array}$ & \\
\hline 3 & $\begin{array}{l}\text { Leogok Rezeky } \\
\text { Gultom }\end{array}$ & Christianity & Muslims & $\begin{array}{l}\text { Prohibiting Muslims to } \\
\text { believe in Muhammad } \\
\text { as a prophet }\end{array}$ & Muslims \\
\hline 4 & $\begin{array}{l}\text { Leogok Rezeky } \\
\text { Gultom }\end{array}$ & & & $\begin{array}{l}\text { Commanding Muslims } \\
\text { to be ashamed of } \\
\text { believing in the } \\
\text { Prophet Muhammad }\end{array}$ & \\
\hline 5 & $\begin{array}{l}\text { Rozaq Ismail } \\
\text { Sudarmadji }\end{array}$ & Islam & Muslims & $\begin{array}{l}\text { Criticizing the use of } \\
\text { Islamic religious } \\
\text { sentiments in the } 2017 \\
\text { DKI Jakarta Regional } \\
\text { Head Election }\end{array}$ & $\begin{array}{l}\text { Muslims who use } \\
\text { religious } \\
\text { sentiments in the } \\
\text { 2017's DKI Jakarta } \\
\text { Gubernatorial } \\
\text { Election }\end{array}$ \\
\hline 6 & $\begin{array}{l}\text { Faizal } \\
\text { Muhammad } \\
\text { Tonong }\end{array}$ & Islam & Muslims & $\begin{array}{l}\text { Warning against } \\
\text { Indonesian Muslims } \\
\text { who have the right to } \\
\text { vote in the } 2019 \\
\text { Presidential Election }\end{array}$ & $\begin{array}{l}\text { President Joko } \\
\text { Widodo }\end{array}$ \\
\hline
\end{tabular}

The element of negation of intimacy relates to a person's decision to take a distance and position against other people. The conflict with the hated party in utterances (1) to (6) is caused by the passion of each speaker. Meanwhile, the element of commitment is the materialization of one's hatred. The materialization is reflected in the illocutionary function chosen by the speaker.

The utterances (1) and (2) materialize hatred in acts of fighting and slaughtering. The word bantai (kill) in speech (2) is an example of implying the internal process of hatred towards the Uber and Grab entities (drivers) manifested into actions that have elements of violence and destruction as meaning components of the word bantai (kill). Speech (2) is in the context of competition between conventional public transportation drivers and online transportation drivers. The competition tends to be won by online transportation. Conventional transportation parties feel that the presence of online transportation disrupts their interests in making a living. The speaker (2) initiated that acts of violence for their economic benefit. Speech (2) is an excellent example to abstract the manifestation of hatred in lingual units that can change the social order. Speech (2) is addressed to the speech partner who is invited to hate. Therefore, hatred and its subsequent manifestations can turn into mass, or not only speakers who have hatred and make a decision (commitment) to eliminate the hated party so that their interests are not disturbed. Speech that has components of such meaning when abstracted according to the type of hate speech, according to Ghanea (2012), may hurt individuals and lead to genocide and terrorism. This escalation can be viewed from aspects that speakers hate. Interpersonal utterances that have specific individual references can only be utterances that result in violence. However, if the utterances contain mass world entities such as gender, ethnicity, religion, sexual orientation, specific professional groups, they can become utterances that result in genocide or terrorism. Moreover, the speaker in the follow-up speech on his Facebook account thought that he plans to do perang (war) as mentioned in utterance (1).

The speaker of speech (3) and (4) is not a Muslim. However, it is not the lack of knowledge that causes the perpetrators to delegitimize the prophethood of Muhammad in Islam; it is due to the authoritarian personality. According to Sternberg and Sternberg (2008, p. 180), people with this personality see the world in black and white. This sharp polarization, of course, places themselves or the things related to them as 
white or right, while the other is black or wrong. With such polarization, people with authoritarian personalities hate differences because a world other than theirs is considered wrong. Hatred of people with authoritarian personality also manifested in lingual units representing supremacy, namely the word jangan. Belief in the truth of themselves makes them not give a chance to negotiate about the ultimate truth. According to Sternberg and Sternberg (2008, pp. 180181), people with such personalities want absolute obedience because they believe their beliefs can create an ideal world. The ideal world generated by matching the world with words is by pronouncing the prohibition for Muslims to believe in Muhammad to make these people leave Islam. Thus, both speakers of speech (1) and (2) and speakers of speeches (3) and (4) aim to eliminate the hated party even though it is not done with physical violence.

The speaker (5) hates the use of sentiment in the 2017 DKI Jakarta Pilkada. This hatred made him decide to change the situation by criticizing. Essentially, the practice of criticism itself can be interpreted as offering a different perspective in looking at a phenomenon and trying to displace the point of view that is the mainstream which is undoubtedly considered inappropriate from an alternative point of view. Therefore, the interlocutor who adheres to the mainstream viewpoint is being invited to change it through criticizing. This utterance (5) uses mild hints (see Blum-Kulka, 1987). Speech (5) does not have an object or element regarding the object that can refer to or indicate a directive speech with a criticizing function. In locutionary terms, declarative utterances are commonly used for assertive speech acts. The indicator element of Islamic religious identity politics in Jakarta's gubernatorial election is also not contained in the utterances. The socio-political contextual factor of the DKI Jakarta gubernatorial election greatly determines the interpretation of speech (5). The absence of an object or element regarding this object makes the criticism unattainable by the people who read it on social media. Moreover, constructing the critical phrase agama Islamnya Indonesia (the Indonesian Islam) can lead to a higher potential of misunderstanding as an expression of hatred.
Regardless of the factuality of the relationship between Jokowi, the communists, the PKI, and the People's Republic of China in contextual utterances (6), the speaker believes this knowledge. With that belief, the speaker decides to disseminate it to the public through his Facebook account to know the terrible effects that can occur if Jokowi becomes president again. Speakers prefer to warn that the participant of the interlocutor is the person who is invited to hate rather than threatening actions that allow him to express hatred directly to those who hate. This choice of action could be caused by the power imbalance between the speaker and Jokowi, who was still serving as president when running in the 2019 presidential election. Threatening actions, as well as warning actions, can be aimed at preventing harmful effects from happening. Besides, prevention is carried out because the speech partner knows the speaker's hatred and realizes the harmful impact that can happen to him if something wrong happens to the speaker. The speech partner cancels his evil intentions to the speaker himself.

By spreading this hatred, the speaker attempts to balance the unequal power between him and Jokowi. Moreover, this communality was formed with the identity of Islam, which is the majority religion in Indonesia; even this warning act could topple down Jokowi's power. The speech incident (6) is in the context of the 2019 Presidential Election, so the perlocutionary effect of not voting for Jokowi during voting can be carried out.

Unfortunately, there are no uploads listed as evidence in the decision letter that explicitly indicates political affiliation in the 2019 presidential election, so we cannot confirm this. However, the speaker's choice of action benefits another presidential candidate, Prabowo Subianto, because the presidential election is only followed by two pairs of presidential and vice-presidential candidates. Presidential candidates other than Jokowi are considered not to have the potential to hurt Muslims in Indonesia.

\section{CONCLUSION}

In terms of illocutionary power and the factors that influence it, the article finds that hate speech on social media in Indonesia acts 
as a directive speech with the functions of inciting, inviting, ordering, prohibiting, criticizing, and warning. The illocutionary force can be divided based on the hate speech participants who can be constituents of speech partners hated by speakers or speech partners who are invited to hate by speakers. Hate speech events with the constituents of the speech partners of the hated party tend to function to incite, order, prohibit, criticize, and warn. In addition to inciting, other functions tend to have or show high coercion so that the speech partner fulfills the future actions desired by the speaker because the speaker views himself as being in a higher position than the speech partner. The speaker feels he has specific authority over the hated party, so he has no voice and determines the value of his own identity. He can only follow the speaker's orders. Therefore, it can be said that hate speech speakers are in an authoritarian ideological position.

Meanwhile, hate speech to speech partners invited to hate only serves to incite and invite those who tend to have low coercive power. The speech partner has more opportunity to act independently of the directive direction of the speaker. In addition, the fulfillment of the actions desired by the speaker by the speech partner is the personal responsibility of the speech partner. The reduction of the speaker's coercive power means a reduction in the portion of responsibility for the actions taken by the speech partner. Therefore, based on the illocutionary function of speech, the speaker's hatred makes him want (1) the obedience of the target of hatred to the speaker's will; (2) identification of the source of the speaker's hatred; or (3) elimination of the target of hatred.

It is crucial to study hate speech from the speaker's perspective to understand the world in the speaker's mind, which conditions its shape and sustains the world in the speaker's mind. However, more importantly, speakers are members of the community who make the world in the speaker's mind also have roots in the community's social world. Therefore, further studies can view hate speech as a crime and a social phenomenon that requires a comprehensive response that erodes the cultural foundation that supports the discriminatory views of speakers. Besides, it significant not to view hate speech as an individual act and detached from the broader socio-cultural contexts surrounding it.

\section{REFERENCES}

Austin, J.L. (1968). How To Do Things With Words. New York: Oxford University Press.

Blum-Kulka, Shoshana. (1987). Indirectness and Politeness in Request: Same or Different?. Journal of Pragmatics, vol. 11, hal. 131-146.

Burhani, Ahmad Najib. (2019). Menemani Minoritas: Paradigma Islam tentang Keberpihakan dan Pembelaan kepada yang Lemah. Jakarta: Gramedia Pustaka Utama.

Butler, Judith. (1997). Excitable Speech: A Politic of the Performative. New York: Routledge.

Butler, Judith. (2010). Performative Agency. Journal of Cultural Economy, DOI: 10.1080/17530350.2010.494117.

Cummings, Louise. (2007). Pragmatik: Sebuah Perspektif Multidisipliner. Yogyakarta: Pustaka Pelajar.

Ghanea, Nazila. (2012). Hate Speech Beyond Border. TEDx EastEnd. 18 Desember 2017, diunduh dari https://www.youtube. com/watch? $v=m S-b V s H q C z U$.

Halliday, M.A.K. (1994). Bagian A. Halliday, M.A.K dan Ruqaiyah Hasan. Bahasa, Konteks, dan Teks: Aspek-aspek Bahasa dalam Pandangan Semiotik Sosial. Yogyakarta: Gadjah Mada University Press.

Kepala Kepolisian Republik Indonesia. (2015). Surat Edaran Kapolri No. SE/6/X/201 mengenai penanganan ujaran kebencian. 
Kimotho, Stephen Gichuhi dan Rahab Njeri Nyaga. (2016). Digitized Ethnic Hate Speech: Understanding Effects of Digital Media Hate Speech on Citizen Journalism in Kenya. Advances in Language and Literary Studies, Vol. 7 No. 3, hal. 189-6. http://dx.doi.org/10.7575/aiac.alls.v.7n.3p.189 Accessed on 17 July 2017.

Langton, Rae. (1993). Speech Acts and Unspeakable Acts. Philosophy \& Public Affairs, Vol. 22, No. 4 (Autumn), hal. 293-330

Langton, Rae. (2012). Beyond Belief: Pragmatics in Hate Speech and Pornography. Speech and Harm: Controversies Over Free Speech, hal. 72-93.

Langton, Rae. (2018). The Authority of Hate Speech. Url: https://www.abc.net.au/religion/theauthority-of-hate-speech/10478626 Accessed on 12 July 2019.

Leech, Geoffre. (1993). Prinsip-prinsip Pragmatik. Jakarta: Penerbit Universitas Indonesia.

Lestari, Dwi Puji. (2016). Ungkapan Kebencian Yang Muncul Pada Fenomena Islamophobia di United Kingdom. Tesis. Universitas Gadjah Mada. Tidak Dipublikasikan.

Miller, Seumas. (2000). Speech Acts and Conventions. Language Sciences, Vol. 22, hal. 155-166.

Moon, Richard. (2018). Putting Faith in Hate: When Religion is The Source or Target of Hate. Cambridge University Press.

Presiden Republik Indonesia. (2015). Undang-Undang No. 19 Tahun 2016 tentang Informasi dan Transaksi Elektronik.

Rustono. (1999). Pokok-pokok Pragmatik. Semarang: CV. IKIP Semarang Press.

Searle, John R. (1968). Austin on Locutionary and Illocutionary Acts. The Philosophical Review, Vol. 77, No. 4. hal, 405-424.

Searle, John R. (1969). Speech Acts: A Essays The Philosophy of Language. Cambrigde: Cambrigde University Press.

Searle, John. R. (1979). Expression and Meaning. New York: Cambridge University Press.

Sternberg, Robert J. dan Karin Sternberg. (2008). The Nature of Hate. United States of America: Cambridge University Press.

Ubaidillah. (2019a). Resignification: Wacana Balik Orang Papua Menanggapi Rasisme. Jurnal Masyarakat dan Budaya, Vol. 21. No. 3, Tahun 2019

Ubaidillah. (2019a). Tinjauan Buku: Peran Agama dalam Ujaran Kebencian: Sumber atau Target. Jurnal Masyarakat Indonesia. Vol. 45, No. 1, 2019.

Waldorn, Jeremy. (2012). The Harm in Hate Speech. London: Harvard University Press.

Whitten, Suzanne. (2019). A Recognition, Authority Relations, and Rejecting Hate Speech, Ethical Theory and Moral Practice, https://doi.org/10.1007/s10677-019-10003-z

Wijana, I Dewa Putu dan Mohammad Rohmadi. (2011). Analisis Wacana Pragmatik: Kajian Teori dan Praktik. Surakarta: Yuma Pustaka.

\section{Webpages}

Putusan Pengadilan Negeri Jakarta Selatan Nomor: 572/Pid.B/2016/PN.Jkt.Sel. (Terdakwa Feriyanto). 2016. Jakarta: Pengadilan Negeri Jakarta Selatan.

https://www.google.com/url?q=https://putusan.mahkamahagung.go.id/putusan/downloadpdf /76093430f39fc831bd94eb6050292568/pdf\&sa=U\&ved=0ahUKEwis4p-

M8KDaAhVPNrwKHTd8DGsQFggEMAA\&client=internal-uds-

cse\&cx=004086544163985272441:foabjjpxdue\&usg=AOvVaw310rmnCvvfXDzVu8K9zFxl.

Accessed on November 10, 2017. 
Putusan Pengadilan Negeri Klaten Nomor : 164/Pid.Sus/2017/PN.Kln. (Terdakwa Rozaq Ismail Sudarmadji). 2017. Klaten: Pengadilan Negeri Klaten.

https://putusan.mahkamahagung.go.id/putusan/d9511c5b6ffe447ceaacd5dbd4fa0cae. Accessed on 5 January 2018.

Putusan Pengadilan Negeri Rantauprapat Nomor: No. 169/Pid.Sus/2017/PN. Rap. (Terdakwa Leogok Hasil Rezeky Gultom). 2017. Rantauprapat: Pengadilan Negeri Rantauprapat.

https://putusan.mahkamahagung.go.id/putusan/db75546d6ebd353cadd4465e738b97f4. Accessed on November 25, 2017.

Putusan Pengadilan Negeri Singkel Nomor: 13/Pid.Sus/2017/PN SKL. (Terdakwa Luhut Nadeak). 2017. Singkel. Pengadilan Negeri Singkel.

https://putusan.mahkamahagung.go.id/putusan/59e58b6f04df207ef24bcbf374eec51a. Accessed on November 20, 2017.

Putusan Pengadilan Negeri Jakarta Utara Nomor : 1105/Pid.Sus/2017/PN.Jkt.Utr. (Terdakwa Muhammad Faizal Tanong). 2017. Jakarta: Pengadilan Negeri Jakarta Utara. https://putusan.mahkamahagung.go.id/putusan/13ff533422ecaa46a130ab1816ee54b1. Accessed on 5 January 2018. 